\title{
ANALISIS POTENSI BUDIDAYA BUAH NAGA SEBAGAI UPAYA MENINGKATKAN PENDAPATAN MASYARAKAT DI KAMPUNG WULUKUBUN KABUPATEN KEEROM
}

\author{
Sarlota Arrang Ratang \\ ratangsarlota@yahoo.com \\ Siti Aminah \\ sitiaminah@gmail.com \\ Michael Ughun \\ ughunmichael@gmail.com
}

Fakultas Ekonomi dan Bisnis Universitas Cenderawasih

\section{Abstraksi:}

Kegiatan agribisnis pertanian yang saat ini masih memiliki potensi berkembang baik adalah budidaya buah nagayang beberapa tahun belakang ini terlihat subur dan berkembang di Kabupaten Keerom kususnya pada Kampung Wulukubun. Peluang untuk membudidayakan buah naga masih sangat terbuka, baik untuk pasaran lokal maupun internasional. Begitu menjanjikan untuk membudidayakan buah naga karena dapat menambah pendapatan petani bagi kesejateraan keluarga.

Untuk itu Kelompok Tani yang akan di jadikan sample penelitian adalah kelompok tani Mekar Karya yang sudah sangat eksis dalam membudidayakan buah naga ini, dengan jumlah reponden 13 petani, dengan tujuan penelitian yang pertama menunjukkan hasil bahwa Tingkat efisiensi menunjukkan bawa R/C rasio usaha tani buah naga pada kelompok tani Mekar Karya Kampung Wulukubun adalah 5,12 hasil dari pembagian antara penerimaan dan biaya total (biaya tetap dan biaya variabel), maka usaha tani budidaya buah naga pada kelompok tani Mekar Karya dinyatakan efisien dan layak untuk dikembangkan atau diusahakan. Dan tujuan ke dua dengan hasil Analisis usaha Tani buah naga pada Kelompok Tani Mekar Karya Kabpuaten Keerom teritung pada tahun kedua pendapatannya sebesar Rp. 1.195.005.000/tahun dan pada tahun ketiga naik pendapatnnya naik menjadi Rp. 1.658.100.000/tahun dengan Estimasi tiap tahun produksi buah naga mengalami kenaikan $1.000 \mathrm{~kg} / \mathrm{bulan}$ dan harga rata-rata Rp. $35.000 / \mathrm{kg}$. Maka dapat dilihat bahwa dari tahun pertama tanam belum mendapatkan keuntungan karena harus mengembalikan modal dan pada saat tanam akan memperoleh hasil minimal 8 bulan setelah menanam, tetapi pada tahun ke dua dan berikutnya terus mengalami kenaikan yang cukup menjanjikan dari sisi produksi maupun sisi pendapatan petani buah naga, pada kelompok tani Mekar Karya Kampung Wulukubun Kabupaten Keerom.

Kata Kunci : Efisiensi, Usaha Tani, Pendapatan, Biaya, dan Produksi

\section{PENDAHULUAN}

\section{A. Latar Belakang}

Kabupaten Keerom merupakan salah satu Kabupaten yang berada di Provinsi Papua, Pada beberapa lokasi, pertanian tanaman pangan di Kabupaten Keerom masih dilakukan dengan sistem tradisional sehingga tingkat produktivitas masih rendah. Akan tetapi pada kawasan-kawasan yang berkembang terutama di wilayah transmigrasi (Distrik Arso dan Distrik Skanto), budidaya tanaman pangan dan hortikultura telah dilakukan secara lebih intensif dan telah menerapkan teknologi budidaya yang modern. Oleh karena itu, sub-sektor pertanian tanaman pangan dan hortikultura mampu menjadi kontributor utama dalam perekonomian sektor pertanian maupun perekonomian wilayah kabupaten.Luas penggunaan lahan untuk tanaman pangan di Kabupaten Keerom pada Tahun Tahun 2010 mencapai 2.227 ha. Dan untuk tanaman hortikultura pada tahun yang sama mencapai luas 1.864 ha.

Komoditas yang menonjol peranannya pada sub-sektor tanaman pangan dan hortikultura adalah Ubi Jalar, Ubi Kayu, dan Padi Sawah.Ketiga komoditas ini merupakan penyumbang utama bagi produk wilayah Kabupaten.Produksi ketiga komoditas pada Tahun 2010 berturut-turut adalah 2.714 ton, 2.360 ton dan 1.287 ton.dan 1.190 ton.Tetapi beberapa tahun terakhir ini khusus buah naga sudah mulai terlihat subur berkembang di Kabupaten Keerom.

Kegiatan agribisnis pertanian yang saat ini masih memiliki potensi berkembang baik adalah budidaya buah naga, yang mana terdapat berpuluh macam tanaman buah yang dapat tumbuh di Indonesia. Hingga saat ini kebutuhan akan buah naga di Indonesia cukup besar. Kebutuhan tersebut belum mampu dipenuhi, baik oleh produsen di dalam negeri maupun di luar negeri, sehingga peluang untuk membudidayakan buah naga masih sangat terbuka, baik untuk pasaran lokal maupun internasional. Peluang usaha buah naga sangat menjanjikan, tidak saja untuk konsumsi segar tetapi juga untuk produk 
kesehatan.8 Buah naga merupakan buah dari beberapa jenis kaktus dari marga Hylocereus dan Selenicereus. Berdasarkan penelitian para ahli gizi, berpendapat bahwa buah naga kaya akan kandungan ferum, potassium, serat, sodium, dan kalsium yang baik untuk kesehatan.

Pohon buah naga dapat berbuah tiga kali setahun.Produksinya bisa terus meningkat selama dirawat dengan baik dan tidak tercemar udara.Buah naga sangat cocok ditanam dilahan kering, dan dalam sekali tanam, usianya dapat bertahan sampai 20 tahun. Bisnis buah naga menjadi alternatif bagi pemberdayaan masyarakat untuk meningkatkan pendapatan, taraf hidup petani setempat masuknya modal atau investasi didaerah lain, membuka kesempatan usaha dan membuka lowongan kerja. Dalam skala makro, bisnis buah naga dapat menyumbang devisa yang cukup besar bagi Negara dan sumber pendapatan bagi pemerintah setempat.

Buah Naga dapat menjadi alternatif dalam meningkatkan pendapatan karena diketahui bahwa harga buah naga di Kota Jayapura saat ini cukup tinggi yaitu kisaran Rp $25.000,00$ hingga Rp 50.000,00 per/kg (untuk buah naga merah dan putih) menjadikan buah naga sebagai buah eksotis yang memiliki nilai jual tinggi.Tak heran bila buah ini akhirnya banyak dilirik oleh petani dan pengusaha agrobisnis untuk dikembangkan.Perawatannya yang cukup mudah dan permintaan tinggi menjadi sebuah peluang pasar dan prospek yang bagus.Antara ketersediaan barang dan permintaan masih terdapat selisih yang tinggi.Artinya, usaha budidaya buah naga sangat prospektif, terutama untuk menghadapi perayaan hari raya baik Natal atau Lebaran.Permintaan pasar modern dan tradisional sangat tinggi untuk buah naga merah.Setiap harinya, permintaan nasional buah naga merah mencapai puluhan ton.Hal ini merupakan peluang pasar yang cukup bagus dan rugi bila diabaikan begitu saja.

Dengan adanya usaha budidaya buah naga maka bisa membantu untuk memenuhi kebutuhan masyarakat pembudidaya yang kurang memadai atau memiliki penghasilan yang sedikit sebelumnya. Melihat prospek dan peluang yang menguntungkan di Kabupaten Keerom memiliki potensi yang besar untuk membudidayakan buah naga dalam skala yang lebih luas dan bernilai tambah dan dapat meningkatkan kesejahteraan petani budidaya buah naga. Dengan usaha ini pembudidaya buah naga di Kabupaten Keerom diharapkan dapat meningkatkan pendapatannya masing-masing, dan tentunya merupakan suatu usaha yang patut digalakkan untuk berkembang sebagai upaya mensejahterakan keluarga.

Para pembudidaya dalam membudidaya buah naga sesuai dengan apa yang dipilihnya berdasarkan pengalaman dan kemampuan dalam membudidaya serta banyaknya minat masyarakat akan mengkonsumsi buah naga, potensi lahan tanah di Kabupaten Keerom yang cocok khususnya di Kampung Wulukubun Arso X1V untuk perkembangan buah naga dan harga saing buah naga yang tinggi dipasaran.

Berdasarkan uraian diatas, melihat adanya potensi usaha budidaya buah naga di Kampung Wulukubun Arso X1V Kabupaten Keerom apakah preferensi pembudidaya tersebut berdampak terhadap peningkatan pendapatan, maka penulis tertarik untuk melakukan penelitian mengenai "Analisis Potensi Budidaya Buah Naga Sebagai Upaya Meningkatkan Pendapatan Masyarakat di Kampung Wulukubun Arso X1V Kabupaten Keerom (studi kasus pada Kelompok Tani Mekar Karya)."

\section{B. Tujuan Penelitian}

Tujuan dari penelitian ini adalah sebagai berikut:

1. Untuk mengetahui Tingkat Efisiensi Budidaya Buah Naga sebagai upaya meningkatkan pendapatan masyarakat Kampung di Kampung Wulukubun Arso X1V Kabupaten Keerom (studi kasus pada Kelompok Tani Mekar Karya).

2. Untuk mengetahui analisis usaha tani budidaya buah naga di Kampung Kampung di Kampung Wulukubun Arso X1V Kabupaten Keerom (studi kasus pada Kelompok Tani Mekar Karya).

\section{KAJIAN TEORI}

\section{A. Konsep Pendapatan}

Dalam penelitian ini, pendapatan yang digunakan adalah pendapatan Petani pemilik lahan. Menurut Sukirno (2002) bahwa pendapatan merupakan balas jasa yang diterima atas keikutsertaan seseorang dalam proses produksi barang dan jasa, pendapatan ini dikenal dengan nama pendapatan dari kerja (Labour Income). Selain pendapatan dari kerja, pekerja sering kali mendapatkan pendapatan lain yang bukan merupakan balas jasa dari kerja, pendapatan bukan dari kerja ini disebut nonlabour income. Pemanfaatan pekerja dapat dilihat dari pendapatan yang diterimna seseorang. Apabila seseorang mempunyai keterampilan tertentu, misalnya diperoleh dari pendidikan atau latihan dan bekerja di suatu lapangan 
usaha dan dalam lingkungan usaha tertentu, maka diharapkan akan diperoleh pendapatan sebesar tertentu yang diperoleh dari pekerjaan tersebut. Berdasarkan hal tersebut diatas maka dapat dikatakan bahwa pendapatan sesorang tergantung pada keterampilan di bidang tertentu yang dapat diperoleh dari pendidikan, latihan keterampilan, dan pengalaman bekerja pada bidang tertentu.

\section{B. Konsep Biaya Produksi}

Menurut Alma (2000) biaya adalah setiap pengorbanan untuk membuat suatu barang atau untuk memperoleh suatu barang yang bersifat ekonomis rasional.Jadi dalam pengorbanan ini tidak boleh mengandung unsur pemborosan sebab segala pemborosan termasuk unsur kerugian, tidak dibebankan ke harga pokok. Jenis dan perilaku biaya merupakan elemen kunci dalam proses penganggaran, terutama menyangkut tanggung jawab manager.

Biaya dapat dibagi menjadi tiga (3) yaitu :

1. Biaya Variabel, yaitu biaya yang berubah-ubah secara langsung dengan tingkat aktivitas yang ada, misalnya komponen penjualan menurut metode komisi langsung

2. Biaya Semi Variabel, yaitu biaya yang bervariasi dengan tingkat aktivitas yang ada tetapi tidak dalam propasi langsung.

3. Biaya tetap, yaitu biaya yang tidak berpengaruh oleh perubahan aktivitas tetapi bersifat konstan selama periode tertentu.

Menurut Boediono (1992), pendapatan dihitung dengan cara mengurangkan total penerimaan dengan total biaya, dengan rumus sebagai berikut

\section{I = TR - TC}

Keterangan :

I = Income (Pendapatan)

$\mathrm{TR}=$ Total Revenue (TotalPenerimaan)

$\mathrm{TC}=$ Total Cost (Total Biaya)

\section{Konsep Luas Lahan}

Pendapatan petani dipengaruhi oleh luas lahan, dimana semakin luas lahan petani maka pendapatannya juga akan meningkat. Hubungan antara luas lahan dengan pendapatan bahwa luas lahan berpengaruh positif terhadap pendapatan/penghasilan petani buah naga. Lahan yang dikelola dengan baik tentunya akan memberikan hasil yang baik dan menguntungkan bagi petani (buah naga).

\section{Konsep Keterampilan}

Menurut Rivai (2004:226) menegaskan bahwa keterampilan adalah proses sistematis mengubah tingkah laku pegawai untuk mencapai tujuan organisasi. Keterampilan berkaitan dengan keahlian dan kemampuan pegawai dalam melaksanakan pekerjaan saat ini.Keterampilan memiliki orientasi saat ini dan membantu pegawai untuk mencapai keahlian dan kemampuan tertentu agar berhasil melaksanakan pekerjaan.

Menurut Simamora (2004:276) bahwa tujuan pemberian keterampilan adalah sebagai berikut : 1) Memperbaiki kinerja. 2) Memutahirkan keahlian para karyawan sejalan dengan kemajuan teknologi. 3) Mengurangi waktu pembelajaran bagi karyawan baru agar konpeten dalam bekerja. 4) Membantu dalam memecahkan masalah operasional. 5) Mempersiapkan karyawan untuk promosi. 6) Mengorientasikan karyawan terhadap organisasi. 7) Memenuhi kebutuhan pertumbuhan pribadi. Dari pendapatan diatas, maka dapat diartikan bahwa tujuan keterampilan itu sebenarnya untuk meningkatkan kecerdasan serta meningkatkan keahlian pegawai pada masing-masing bidang pekerjaan agar nantinya dapat bekerja secara efektif dan efisien.

\section{E. Konsep Jumlah Tenaga Kerja}

Menurut Simanjuntak (1990:69) tenaga kerja (man power) mengandung pengertian. Pertama, tenaga kerja mengandung pengertian usaha kerja atau jasa yang dapat diberikan dalam proses produksi. Dalam hal ini tenaga kerja mencerminkan kualitas usaha yang diberikan oleh seseorang dalam waktu tertentu untuk menghasilkan barang dan jasa.Kedua, tenaga kerja mencakup orang yang mampu bekerja untuk memberikan jasa atau usaha kerja tersebut, mampu 
bekerja berarti mampu melakukan kegiatan yang mempunyai nilai ekonomis yaitu kegiatan tersebut menghasilkan barang atau jasa untuk memenuhi kebutuhan masyarakat.

Menurut Mulyadi Subri (2002:57), tenaga kerja (man power) adalah penduduk dalam usia kerja (15-64 tahun) yang dapat memproduksi barang dan jasa jika ada permintaan terhadap mereka dan mereka mau berpartisipasi dalam aktivitas tersebut. Tenaga kerja atau man power terdiri dari angkatan kerja dan bukan angkatan kerja. Menurut Simanjuntak (1990:16) angkatan kerja dibedakan dalam 3 golongan yaitu : 1) Penganggur (open unemployment), yaitu orang yang sama sekali tidak bekerja dan berusaha mencari pekerjaan. 2) Setengah pengangguran (underemployment), yaitu jam kerja mereka kurang dimanfaatkan, sehingga produktivitas kerja dan pendapatan mereka rendah. Setengah pengangguran dapat dibedakan menjadi dua, yaitu : (1) Setengah pengangguran kentara (visible underempyoment) yakni mereka yang bekerja kurang dari 35 jam seminggu, dan (2) Setengah pengangguran tidak kentara (invisible underemployment) yaitu mereka yang produktivitas kerja dan pendapatannya rendah (3) Bekerja penuh, dimana dalam prakteknya suatu negara telah mencapai tingkat penggunaan tenaga kerja penuh bila dalam perekonomian tingkat penganggurannya kurang dari 4 persen (Sukirno, 1997:19-20). Sedangkan untuk golongan bukan angkatan kerja merupakan bagian dari penduduk bukan angkatan kerja yang non aktif secara ekonomi. Mereka terdiri dari yang bersekolah, mengurus rumah rangga, penerimaan pensiun, mereka yang hidupnya tergantung pada orang lain karena lanjut usia, cacat, dalam penjara atau sakit kronis. Hubungan tenaga kerja dengan pendapatan bahwa tenaga kerja berpengaruh positif terhadap pendapatan/penghasilan Petani dengan melihat kebutuhan akan tenaga kerja pada perusahaan tersebut. Akan tetapi penyerapan jumlah tenaga kerja tentunya tidak berlebihan karena akan meningkatkan biaya. Tenaga kerja berperan penting dalam sebuah usaha karena dapat membantu productivitas perusahaan.

\section{METODE PENELITIAN}

Penelitian ini dilakukan di Kampung Wulukubun Arso XIV pada Kelompok Tani Mekar Karya Kabupaten Keerom dimana Kampung Wulukubun termasuk salah satu daerah yang mempunyai tingkat produksi buah naga yang tinggi di Kabupaten Keerom

Teknik pengambilan sampel menggunakan metode Puposive Sampling. Dalam Purposive Sampling, Setiap elemen populasi mempunyai kemungkinan pemilihan yang sama (Sri Budi Cantika Yuli, 2006). Penelitian ini menggunakan jenis penelitian analisis diskriptif kuantitatif yaitu dengan mengumpulkan data-data mengenai laporan keuangan. Penelitian melakukan pengamatan terhadap objek penelitian yang dipilih, kemudian dianalisa dan disimpulkan (Idah Zuhroh, 2012).

Data yang digunakan adalah data primer.Data primer dalam penelitian ini diperoleh langsung dari objek penelitian yang diamati. Sedangkan, metode yang digunakan dalam pengambilan data adalah metode survei dengan teknik wawancara kepada petani bedasarkan kuesioner yang berisikan suatu rangkaian pertanyaan mengenai pendapatan petani buah naga di Kelompok Tani Mekar Karya Kampung Wulukubun Kabupaten Keerom

Populasi adalah wilayah generalisasi yang terdiri atas objek/subjek yang mempunyai kualitas dan karakteristik tertentu yang diterapkan oleh peneliti untuk dipelajari dan kemudian ditarik kesimpulannya. Sementara, sampel adalah jumlah unit yang akan diteliti atau dianalisa. Populasi dalam penelitian ini adalah anggota kelompok Tani Mekar Karya naga yang berjumlah 13 orang. karena petani dalam penelitian rata-rata mempunyai luas lahan satu hektar (ha) maka teknik penetuan sampel disamakan dengan jumlah populasi adalah 13 petani .

Adapun Variabel Total Fixed Cost (TFC) diantaranya adalah

a). Luas lahan dalam penilitian ini merupakan luas area yang ditanami dengan tanaman buah naga satu kali masa tanam dengan satuan Hektar (ha).

b). Tenaga kerja dalam penelitian ini merupakan jumlah tenaga kerja yang digunakan per kegiatan dalam satu masa tanam dengan satuan Hari Orang kerja (HOK).

c). Bibit dalam penelitian ini merupakan jumlah bibit dalam proses produksi dalam satu kali masa tanam dengan satuan per Batang.

Variabel Total Variabel Cost (TVC) diantaranya ialah

a). Pupuk dalam penelitian ini merupakan total penggunaan pupuk dalam satu kali masa tanam dengan satuan Kilogram $(\mathrm{kg})$. 
b). Petisida dalam penelitian ini merupakan total penggunaan semua petisida dalam satu kali masa tanam dengan satuan Liter (L).

Metode Analisis yang digunakan dalam penelitian ini adalah

Total Biaya petani buah naga di Kampung Wulukubun dapat dihitung dengan rumus sebagai berikut:

\section{$\mathrm{TC}=\mathrm{TFC}+\mathrm{TVC}$}

Keterangan:

$\mathrm{TC}=$ Biaya Total/Total Cost

TFC = Total Biaya Tetap

TVC = Total Biaya Variabel

Penerimaan untuk Mengetahui Total Penerimaan (TR) dari Petani Buah Naga di Kampung Wilukubun dapat menggunakan rumus sebagai berikut:

$T R=P, Q$

Dimana :

$\mathrm{TR}=$ Total Reveneu

$P=$ Harga (Price)

$Q=$ Jumlah Output Andri Setiawan, Aris Soelistyo, Sudarti159: 3 )

Teori Pendapatan Untuk mengetahui tingkat pendapatan bersih Petani Buah Naga menggunakan alat ukur dengan rumus sebagai berikut :

$\pi=\mathrm{TR}-\mathrm{TC}$

Dimana :

$\pi=$ Pendapatan Bersih

$\mathrm{TR}=$ Total Pendapatan (Total Renenue)

$\mathrm{TC}=$ Total Biaya (Total Cost).

Teori Break Event Point (BEP)

Break Event Point (BEP) merupakan titik impas dalam usaha. Dari nilai BEP dapat diketahui pada tingkat produksi dan harga berapa suatu usaha tidak mendapatkan keuntungan dan kerugian.Dapat dirumuskan sebagai berikut.

\section{Break Event Point $(B E P)=$}

Keterangan:

Jika BEP < jumlah produksi maka usaha ini layak diusahakan.

Jika BEP > jumlah produksi maka usaha ini tidak layak untuk diusahakan.

Jika BEP = jumlah produksi maka usaha ini dalam keaadaan titik impas 


\section{HASIL DAN PEMBAHASAN}

\section{A. Karakteristik Responden}

Berdasarkan jenis kelamin petani buah naga pada Kelompok Tani Mekar Karya Kampong Wulukubun Arso 14 mayoritas adalah berjenis kelamin laki laki. Sebanyak 12 responden (92,30\%) adalah laki laki dan sebanyak 1 responden $(7,69 \%)$ adalah perempuan. Dengan demikian usaha buah naga pada kelompok tani mekar karya dikampung wulukubun arso 14 pada umumnya adalah laki laki hal ini sebabkan karena perempuan lebih banyak menghabiskan waktu untuk mengurus anak-anak dan keluarga, dan sebagian waktunya dengan membuka usaha dirumah seperti kios atau usahausaha rumahan lainnya.

Untuk Usia adalah salah satu factor terpenting baik dalam suatu usaha, aktivitas dan juga salah indicator yang akan menentukan produktivitas kerja dalam melakukan pengembagan usaha. Usia atau Umur petani yang relative muda lebih kuat bekerja, mudah menerima inovasi baru, tanggap terhadap lingkungan sekitar bila dibandingkan dengan tenaga kerja yang sudah memiliki usia yang relatif tua sering menolak inovasi baru (soekarti, 2005) hal ini menunjukan bahwa umur responden petani buah naga yang terbesar pada kelompok umur 35-40 sebanyak 6 orang dengan persentase 46,15\%, 4145 tahun sebanyak 2 orang dengan persentase 15,38\%, 46-49 tahun sebanyak 1 orangdengan persentase 7,69\% dan umur 50-55 tahun sebanyak 4 orang dengan persentase 30,76\%. Undang undang no.13 tahun 2003 disebutkan bahwa tenaga kerja yang produktif adalah tingkat umur rata-rata 15-64 tahun. Dengan demikian usaha buah naga pada kelompok tani mekr karya kampong wulukubun didominasi oleh kelompok umur produktif yaitu 13 orang dengan persentase $100 \%$

Selanjutnya adalah Tingkat pendidikan.Pendidikan akan mempengaruhi cara kerja, ataupun kemampuan dalam pengambilan keputusan seseorang, kecepatan adopsi inovasi baru, pengolahan usaha tani hingga pemasaran. Dengan hasil penelitian yang dilakukan terhadap petani buah naga pada kelompok tani mekar karya kampong wulukubun dapat di ketahui bahwa petani memiliki tingkat pendidikan yang berbeda beda, dapat dilihat bahwa tingkat pendidikan petani yang paling banyak adalah SMA yaitu sebanyak 7 orang atau $53,84 \%$, smentra petani yang berpendidikan SGSLP dan SMK sebanyak 1 dan 5orang saja atau hanya $7,69 \%$ dan $3846 \%$. Jadi dapat dikatakan bahwa petani responden pada kelompok tani mekar karya kampong wulukubun adalah rata rata berpendidikan menengah yaitu SMA dan diikuti dengan SMK.

Selanjutnya untuk lamanya memulai usaha, dapat dilihat pada tahun tanam buah naga dapat dlihat dari tahun tanam 2013 sampai dengan tahun 2017, dari 13 responden, maka tahun tanam 2013 ada 1 responden yang sudah memulai usaha menanam buah naga, diikuti tahun 2014 ada 1 responden juga yang mulai menanam buah naga dan terus mengalami kenaikan pada tahun 2015 sebanyak 3 responden, demikian pula tahun 2016 mengalami kenaikan 4 responden petani , dan pada tahun 2017 ada 4 responden petani buah naga yang baru memulai tanam buah naga.

\section{B. Biaya budidaya buah naga}

Biaya merupakan pengorbanan yang dimasukan dalam proses produksi baik sebelum dan selama usaha itu berjalan. Diketahui bahwa untuk menghitung total biaya yang dikeluarkan oleh petani responden buah naga dapat dimasukan dalam rumus $\mathrm{TC}=\mathrm{FC}+\mathrm{VC}$ biaya yang dikeluarkan adalah biaya pembelian balok, pembelian ban (penyangga), biaya tenaga kerja dan biaya peralatan.

Biaya tetap, adalah Biaya yang tetap konstan pada berbagai tingkat output yang dihasilkan oleh suatu usaha dikenal sebagai biaya tetap. Biaya ini tidak terpengaruh oleh fluktuasi sesaat dalam tingkat aktivitas kegiatan, Walaupun biaya ini tetap dan konstan bukan berarti bahwa biaya ini tidak akan berubah di masa depan. Biaya ini cenderung dapat tidak dapat diubah dalam jangka pendek. Dalam usahatani buah naga pada kelompok ini yang termasuk dalam biaya tetap adalah biaya pembelian bibit, pembelian balok, pembelian ban dan biaya pembelian peralatan pertanian.

Dikatakan sebagai biaya tetap kerena bibit buah naga bukan tanaman yang sekali panen tetapi merupakan tanaman dengan panjang sklus produktifnya $15-20$ tahun. Untuk kelompok tani mekar karya menggunkan bibit rata-rata 381 bibit dengan harga perbibit adalah Rp.20.000/batang. Balok yang digunakan juga termasuk biaya tetap karen dipakai dalam jangka waktu yang lama. Dimana balok yang di beli sebagai tiang penyangga pohon buah naga, dengan rata-rata pemakaian adalah 29 batang balok, harga per balok $10 \times 10$ adalah Rp.80.000/ balok. Untuk ban penyangga dengan rata-rata penggunaan ban tiap petani adalah 219 ban dan harga per ban penyangga adalah Rp.5.000/ban. Selain itu ada biaya peralatan yang telah dihitung penyusutannya, yang mana peralatan tersebut adalah cangkul, sabit, parang, profil tank, selang, sanyo, penyemprot. Biaya peralatan tersebut setela diitung penyusutannya adalah rata-rata adalah Rp 166.000 dan terakhir yaitu pembelian kendaraan roda 4 yaitu Rp. 150.000 .000 
Biaya Tetap Usaha Tani Buah Naga di Kelompok Tani Mekar Karya

Kampung Wulukubun Kabupaten Keerom

\begin{tabular}{|c|c|c|c|c|c|}
\hline No & $\begin{array}{l}\text { Bibit (btg) } \\
@ \text { rp.20.000/btg }\end{array}$ & $\begin{array}{l}\text { Balok 10X10 @ } \\
80.000 / \text { btg (Rp) }\end{array}$ & $\begin{array}{l}\text { Ban Penyangga } \\
@ 5.000 / \mathrm{bh} \\
\text { (Rp) }\end{array}$ & $\begin{array}{l}\text { Penyusutan } \\
\text { peralatan (Rp) }\end{array}$ & $\begin{array}{l}\text { Total biaya Tetap } \\
\text { (Rp) }\end{array}$ \\
\hline 1 & Rp.750.000 & Rp. 2.000.000 & Rp. 1.000 .000 & Rp. 166.000 & Rp.3.916.000 \\
\hline 2 & Rp.750.000 & Rp. 2.000 .000 & Rp. 1.000.000 & Rp. 166.000 & Rp.3.916.000 \\
\hline 3 & Rp. 600.000 & Rp.2.000.0000 & Rp. 750.000 & Rp. 166.000 & Rp3.516.000 \\
\hline 4 & Rp. 600.000 & Rp.2.000.0000 & Rp. 1.000 .000 & Rp. 166.000 & Rp.3.766.000 \\
\hline 5 & Rp. 600.000 & Rp.2.000.0000 & Rp. 1.000 .000 & Rp. 166.000 & Rp.3.766.000 \\
\hline 6 & Rp. 600.000 & Rp.2.000.0000 & Rp. 1.000 .000 & Rp. 166.000 & Rp.3.766.000 \\
\hline 7 & Rp.800.000 & Rp.2.000.0000 & Rp. 1.250 .000 & Rp. 166.000 & Rp.4.216.000 \\
\hline 8 & Rp.800.000 & Rp.2.000.0000 & Rp. 1.250.000 & Rp. 166.000 & Rp.4.216.000 \\
\hline 9 & Rp.800.000 & Rp.2.000.0000 & Rp. 750.000 & Rp. 166.000 & Rp.3.716.000 \\
\hline 10 & Rp. 800.000 & Rp.2.000.0000 & Rp. 750.000 & Rp. 166.000 & Rp.3.716.000 \\
\hline 11 & Rp.800.000 & Rp.2.000.0000 & Rp. 750.000 & Rp. 166.000 & Rp.3.716.000 \\
\hline 12 & Rp.1.000.000 & Rp. 4.000 .000 & Rp. 1.875 .000 & Rp. 166.000 & Rp.7.041.000 \\
\hline 13 & Rp.1.000.000 & Rp. 4.000 .000 & Rp. 1.875 .000 & Rp. 166.000 & Rp.7.041.000 \\
\hline
\end{tabular}

Sumber data : diolah 2019

Biaya Variabel adalah Biaya yang berubah dengan perubahan kuantitas output yang dihasilkan dikenal sebagai Biaya Variabel. Biaya ini secara langsung dipengaruhi oleh fluktuasi tingkat aktivitas usaha, Biaya ini bervariasi dengan variasi volume, yaitu ketika ada peningkatan dalam produksi, biaya variabel ini juga akan meningkat secara proporsional dengan persentase yang sama, jadi ketika tidak ada produksi maka tidak akan ada biaya ini

\section{Biaya Variabel Usaha Tani Buah Naga di Kelompok Tani Mekar Karya Kampung Wulukubun Kabupaten Keerom}

\begin{tabular}{|c|c|c|c|c|c|}
\hline No & $\begin{array}{l}\text { Tenaga kerja } \\
\text { @3jt/tenaga kerja } \\
\text { (Rp) }\end{array}$ & $\begin{array}{l}\text { Pupuk Organik } \\
\text { (Rp) }\end{array}$ & $\begin{array}{l}\text { Pupuk NPK } \\
\text { (Rp) }\end{array}$ & $\begin{array}{l}\text { Petisida } \\
\text { (Rp) }\end{array}$ & $\begin{array}{l}\text { Total biaya Tetap } \\
\text { (Rp) }\end{array}$ \\
\hline 1 & Rp.6.000.000 & Rp. 625.000 & Rp. 300.000 & Rp. 300.000 & Rp.7.225.000 \\
\hline 2 & Rp.9.000.000 & Rp. 625.000 & Rp. 300.000 & Rp. 300.000 & Rp.10.225.000 \\
\hline 3 & Rp.3.000.000 & Rp. 550.000 & Rp. 200.000 & Rp. 200.000 & Rp1.716.000 \\
\hline 4 & Rp.3.000.000 & Rp. 550.000 & Rp. 200.000 & Rp. 200.000 & Rp. 3.950 .000 \\
\hline 5 & Rp.3.000.000 & Rp. 550.000 & Rp. 200.000 & Rp. 200.000 & Rp. 3.950 .000 \\
\hline 6 & Rp.3.000.000 & Rp. 550.000 & Rp. 200.000 & Rp. 200.000 & Rp. 3.950 .000 \\
\hline 7 & Rp.3.000.000 & Rp. 700.000 & Rp. 375.000 & Rp. 375.000 & Rp.4.450.000 \\
\hline 8 & Rp.3.000.000 & Rp. 700.000 & Rp. 375.000 & Rp. 375.000 & Rp.4.450.000 \\
\hline 9 & Rp.3.000.000 & Rp. 700.000 & Rp. 375.000 & Rp. 375.000 & Rp.4.450.000 \\
\hline 10 & Rp.3.000.000 & Rp. 700.000 & Rp. 375.000 & Rp. 375.000 & Rp.4.450.000 \\
\hline 11 & Rp.3.000.000 & Rp. 700.000 & Rp. 375.000 & Rp. 375.000 & Rp.4.450.000 \\
\hline 12 & Rp.3.000.000 & Rp.770.000 & Rp. 400.000 & Rp. 400.000 & Rp.4.570.000 \\
\hline 13 & Rp.6.000.000 & Rp.770.000 & Rp. 400.000 & Rp. 400.000 & Rp.7.570.000 \\
\hline
\end{tabular}

Sumber data : diolah 2019

Untuk biaya variabel pada usaha budidaya buah naga terdiri dari biaya tenaga kerja, biaya pupuk organik, biaya pupuk NPK, dan biaya petisida. Untuk rinciannya dapat dilihat pada tabel diatas. Dimana biaya tenaga kerja rata-rata petani menggunakan 1-3 tenaga kerja dengan biaya tenaga kerja Rp.3.000.000/ tenaga kerja perbulannya. Sedangkan pupuk organik yang digunakan adalah sekitar Rp.550.000 - Rp. 770.000, dan pupuk NPK sekitar diharga Rp. 200.000 - Rp. 
400.000, demikian pula dengan petisida diantara arga Rp. 200.000 - Rp.400.000 penggunaan tiap bulannya. Baik itu tenaga kerja, pupuk dan petisida semua hitungannya dalam bulan.

\section{Produksi budidaya Buah Naga}

Dalam memperoleh hasil produksi yang maksimal, seorang petani akan mengalokasikan input atau factor produksi seefisien mungkin guna tercapai keuntungan yang maksimal. Dalam Penelitian ini petani memproduksi buah naga perbulan sangat berbeda tergantung tahun tanam buah naga.Hasil penelitian menunjukkan bahwa tahun tanam buah naga berumur 1 tahun menghasilkan $2.000 \mathrm{~kg} / \mathrm{ha}$ setiap bulannya. Sedangkan tanaman buah naga berumur 2 tahun dapat menghasilkan $3.000 \mathrm{~kg} / \mathrm{ha}$ setiap bulannya. Sedangkan tanaman berumur 3-4 tahun dapat menghasilkan buah naga sebanyak $4.000 \mathrm{~kg} / \mathrm{ha}$ setiap bulannya.

Penerimaan dalam usaha tani adalah perkalian antara hasil produksi buah naga dan harga jual.Hasil produksi buah naga hingga penerimaan ditentukan oleh besar kecilnya produksi buah naga dan harga jual yang berlaku umum saat itu. Dengan demikian untuk penerimaan petani buah naga dihitung dengan rumus :

\section{$R=Q X P$.}

Maka hasil penelitian menunjukkan bahwa rata-rata penerimaan petani buah naga adalah Rp.57.211.536,-dengan kisaran penerimaan antara Rp. 35.000 .000 - Rp. 78.750 .000 dengan luas lahan selurunya 6,5 ha(0,5 /petani). Dimana rata-rata produksi perbulan $1.000-2.250 \mathrm{~kg} / \mathrm{ha}$ dengan harga jual Rp.35.000/kg.

\section{Pendapatan budidaya buah naga}

Besarnya pendapatan yang diterima petani buah naga merupakan hasil dari jumlah produksi buah naga dalam satu kali panen dikali dengan harga jual/kg dikurangi dengan total biaya. Total biaya dibagi menjadi dua yaitu biaya tetap dan biaya variabel. Dapat diliat pada tabel berikut ini

\section{Pendapatan Budidaya Buah naga Pada Kelompok Tani Mekar Karya}

\begin{tabular}{|l|l|l|l|l|}
\hline No & $\begin{array}{l}\text { Rata-rata } \\
\text { penerimaan }\end{array}$ & $\begin{array}{l}\text { Rata-rata biaya } \\
\text { tetap (Rp) }\end{array}$ & $\begin{array}{l}\text { Rata-rata biaya Variabel } \\
\text { (Rp) }\end{array}$ & Rata-rata Pendapatan (Rp) \\
\hline 1 & Rp. 57.211 .536 & Rp. 4.311 .000 & Rp. 5.031 .000 & Rp. 47.869.536,- \\
\hline & & & & \\
\hline
\end{tabular}

Sumber data: diolah 2019

Dari table diatas menunjukkan bahwa rata-rata pendapatan petani buah naga pada kelompok tani Mekar Karya adalah Rp.47.869.536, hal ini dengan asumsi telah mendapatkan hasil ini setelah diatas 1 tahun tanam terlewati. Karena pada 1 tahun tanam buah naga belum mendapatkan hasil (keuntungan). Maka hasil dari jumlahrata-rata penerimaan Rp. 57.211.536 dikurangi dengan rata-rata biaya tetap adalah Rp.4.311.000 ditambakan dengan rata rata biaya variabel adalah Rp. 5.031.000 ,

Jika R/C Rasio > 1, maka usahatani buah naga efisien atau layak untuk diusahakan. Dan jika R/C Rasio $<1$, maka usahatani buah naga tidah efisien atau tidak layak untuk diusahakan. Untuk mengetahui tingkat efisien dan atau tidak efisien pada usahatani Mekar Karya Kampung Wulukubun, maka dapat dianalisis menggunakan rumus :

\section{R/C Ratio = TR/TC}

Lebih jelas dapat dilihat pada table berikut ini.

Tingkat efisiensi buah naga pada kelompok tani Mekar Karya

\begin{tabular}{|l|l|l|c|}
\hline No & $\begin{array}{l}\text { Rata-rata biaya } \\
\text { total }\end{array}$ & Rata-rata pendapatan & R/C Ratio \\
\hline 1 & Rp. 9.342 .000 & Rp. 47.869.536 & 5,12 \\
\hline & & & \\
\hline
\end{tabular}

Sumber data : diolah 2019 
Sesuai hasil tabel diatas, menunjukkan bawa R/C rasio usaha tani buah naga pada kelompok tani Mekar Karya Kampung Wulukubun adalah 5,12 hasil dari pembagian antara penerimaan dan biaya total (biaya tetap dan biaya variabel), maka usaha tani budidaya buah naga pada kelompok tani Mekar Karya dinyatakan efisien dan layak untuk dikembangkan atau diusahakan.

Analisis Usaha Tani Budidaya Buah Naga pada Kelompok Tani Mekar Karya Kampung Wulukubun.

Biaya Tahun Pertama (1)

Bibit Tanaman 381 batang X Rp. $20.000=$ Rp. 7.620.000,-

Pupuk Organik Rp. 625.000 X 12 bulan $=$ Rp. 7.500.000,-

Pupuk NPK Rp. $300.000 \times 12$ bulan= =Rp. $3.600 .000,-$

Petisida Rp. $300.000 \times 12$ bulan = Rp. $3.600 .000,-$

Tenaga Kerja Rp. $6.000 .000 \times 12$ bulan $=$ Rp. $7.200 .000,-$

Tiang papan 29 papan balok X Rp. $80.000=$ = Rp. $2.160 .000,-$

Ban penyangga 249 ban X Rp. $5.000=$ Rp. $1.249 .000,-$

Biaya Kendaraan roda $4 \quad=R p \cdot 150.000 .000$

Biaya Penyusutan peralatan $\quad=$ Rp. 166.000,-

Total Biaya

$=$ Rp. 183.095.000,-

Biaya Tahun kedua (2)

Pupuk Organik Rp. $625.000 \times 12$ bulan

Pupuk NPK Rp. $300.000 \times 12$ bulan

Petisida Rp. $300.000 \times 12$ bulan

$=$ Rp. 7.500.000,-

$=\operatorname{Rp} .3 \cdot 600.000,-$

Tenaga Kerja Rp. $6.000 .000 \times 12$ bulan

$=$ Rp. 3.600.000,-

Total Biaya

$=$ Rp. $7.200 .000,-$

Total biaya tiga tahun

Tahun pertama $=$ Rp. 183.095 .000

Tahun kedua $=$ Rp. 21.900 .000

Tahun ketiga $=$ Rp. 21.900 .000

\section{Pendapatan pada tahun pertama}

Produksi $2.000 \mathrm{~kg}$ X Rp. $35.000=$ Rp. $70.000 .000,-X 2$ bulan $=$ Rp. 140.000 .000

Maka Penerimaan - produksi

Rp. $140.000 .000-$ Rp.183.095.000 = Rp. -43.095 .000 ,-

Jadi penerimaan tahun pertama adalah Rp. (43.095.000) masih belum mendapatkan keuntungan, masih memutar modal.

Dan juga buahh naga akan dipanen setelah 8 bulan di tanam, maka akan mendapat penerimaan pada 2 bulan saja.

\section{Pendapatan pada tahun kedua}

Produksi $3.000 \mathrm{~kg} \mathrm{X} \mathrm{Rp.} 35.000$ Rp. 105.000.000,- X 12 bulan = Rp.1.260.000.000

Maka Penerimaan - produksi

Rp. $1.260 .000 .000-$ Rp. $21.900 .000=$ Rp. 1.238.100.000,-

Jadi pendapatan tahun kedua adalah Rp. 1.238.100.000, dikurangi Rp. 43.095 .000 maka hasilnya adalah

Rp. 1.195.005.000/tahun

Atau dapat dihitung pendapatan tiap bulan adalah Rp. 99.583 .750

\section{Pendapatan pada tahun ketiga}

Produksi $4.000 \mathrm{kgXRp} .35 .000=$ Rp. $140.000 .000, X 12$ bulan $=$ Rp. 1.680 .000 .000 
Maka Penerimaan - produksi

Rp.1.680.000.000 - Rp. $21.900 .000=$ Rp.1.658.100.000,-

Jadi penerimaan tahun kedua adalah Rp. 1.658.100.000/tahun

Atau dapat dihitung pendapatan tiap bulan adalah Rp. 138.175.000

Estimasi tiap tahun produksi buah naga naik $1.000 \mathrm{~kg} /$ bulan dan harga rata-rata Rp. $35.000 / \mathrm{kg}$. Maka dapat dilihat bahwa dari tahun pertama tanam belum mendapatkan keuntungan karena harus mengembalikan modal dahulu juga pada saat tanam akan memperoleh hasil minimal 8 bulan setelah menanam, tetapi pada tahun ke dua dan berikutnya terus mengalami kenaikan yang cukup menjanjikan dari sisi produksi maupun sisi pendapatan petani buah naga, dimana pada tahun kedua sebesar Rp. 1.195.005.000/tahundan pada tahun ketiga naik menjadi Rp. 1.658.100.000/tahunpada kelompok tani Mekar Karya Kampung Wulukubun Kabupaten Keerom.

\section{PENUTUP}

\section{A. Simpulan}

Dari hasil penelitian dan pembahasan pada bab sebelumnya, maka dapat disimpulkan bahwa rata-rata responden yang menggarap kebun buah naga adalah laki-laki yaitu 99\%, dengan usia antara 30-50 tahun, tahun tanam mulai dari tahun 2013 sampai tahun 2017 terus mengalami kenaikan, adapun tujuan dari penelitian ini menujunkkan bahwa:

1. Tingkat efisiensi menunjukkan bawa $\mathrm{R} / \mathrm{C}$ rasio usaha tani buah naga pada kelompok tani Mekar Karya Kampung Wulukubun adalah 5,12 hasil dari pembagian antara penerimaan dan biaya total (biaya tetap dan biaya variabel), maka usaha tani budidaya buah naga pada kelompok tani Mekar Karya dinyatakan efisien dan layak untuk dikembangkan atau diusahakan.

2. Analisis usaha Tani buah naga pada Kelompok Tani Mekar Karya Kabpuaten Keerom dengan Estimasi tiap tahun produksi buah naga mengalami kenaikan $1.000 \mathrm{~kg} /$ bulan dan harga rata-rata Rp. $35.000 / \mathrm{kg}$. Maka dapat dilihat bahwa dari tahun pertama tanam belum mendapatkan keuntungan karena harus mengembalikan modal dan pada saat tanam akan memperoleh hasil minimal 8 bulan setelah menanam, tetapi pada tahun ke dua dan berikutnya terus mengalami kenaikan yang cukup menjanjikan dari sisi produksi maupun sisi pendapatan petani buah naga, dimana pada tahun kedua sebesar Rp. 1.195.005.000/tahun dan pada tahun ketiga naik menjadi Rp. 1.658.100.000/tahun pada kelompok tani Mekar Karya Kampung Wulukubun Kabupaten Keerom.

\section{B. Saran}

1. Proses perluasan lahan dan penanaman buah naga akan terus meningkatkan produksinya dari tahun ke tahun karena semakin banyaknya peminat ataupun masi terbuka lebar pasarnya. Namun ada beberapa hal (fasilitas) yang perlu disiapkan adalah: a. Unit green hause atau rumah pembibitan; b. Unit rumah panen atau ruma penyimpanan buah naga; c. Unit karantina bibit; $d$. Unit penyiraman kebun yang belum memadai; e. UPO, rumah pupuk organis.

2. Maka, penulis sarankan kepada pemerintah setempat dalam hal ini, Bupati, Dinas tanaman pangan dan holtikultura, dan dinas terkait lainnya untuk dapat membantu menyediakan fasilitas diatas, agar Kampung Wulukubun khususnya kedepan akan menjadi icon buah naga atau pengahasil buah naga termaju di Provinsi Papua. 


\section{DAFTAR PUSTAKA}

[1]. Aliansyah Teuku dkk. 2012. Pengaruh Dimensi Kualitas Pelayanan Terhadap Kepuasan Nasabah Bank Aceh Syariah. PP.1-9 Vol,1No,1 Aceh.

[2]. Sukirno, Sadono. 2002. Teori Mikro Ekonomi. Cetakan Keempat Belas. Rajawali Press: Jakarta.

[3]. Boediono. 1992. Teori Pertumbuhan Ekonomi. Yogyakarta, BPFE UGM.

[4]. Abun, A. Rifai, 2004. Konsep Otonomi Daerah Kabupaten Ogan Komering llir (Dalam Perspektif Utilitarianisme John Stuart Mill). Tesis, Fakultas Filsafat Universitas Gadjah Mada, Yogyakarta.

[5]. Simanjuntak, P. J. 1996. "Pengantar Ekonomi Sumberdaya Manusia". Fakultas Ekonomi, Universitas Indonesia, Jakarta

[6]. Soekartawi, 1991, Agribisnis Teori dan aplikasinya PT. Raja Grafindo Persada Jakarta

[7]. Alma, 2000, Manajemen Pemasaran dan pemasaran jasa, Bandung, ALFABETA

[8]. Henry Simamora. 2004. Manajemen Sumber Daya Manusia. Edisi Ke-3.STIE YKPN.Yogyakarta.

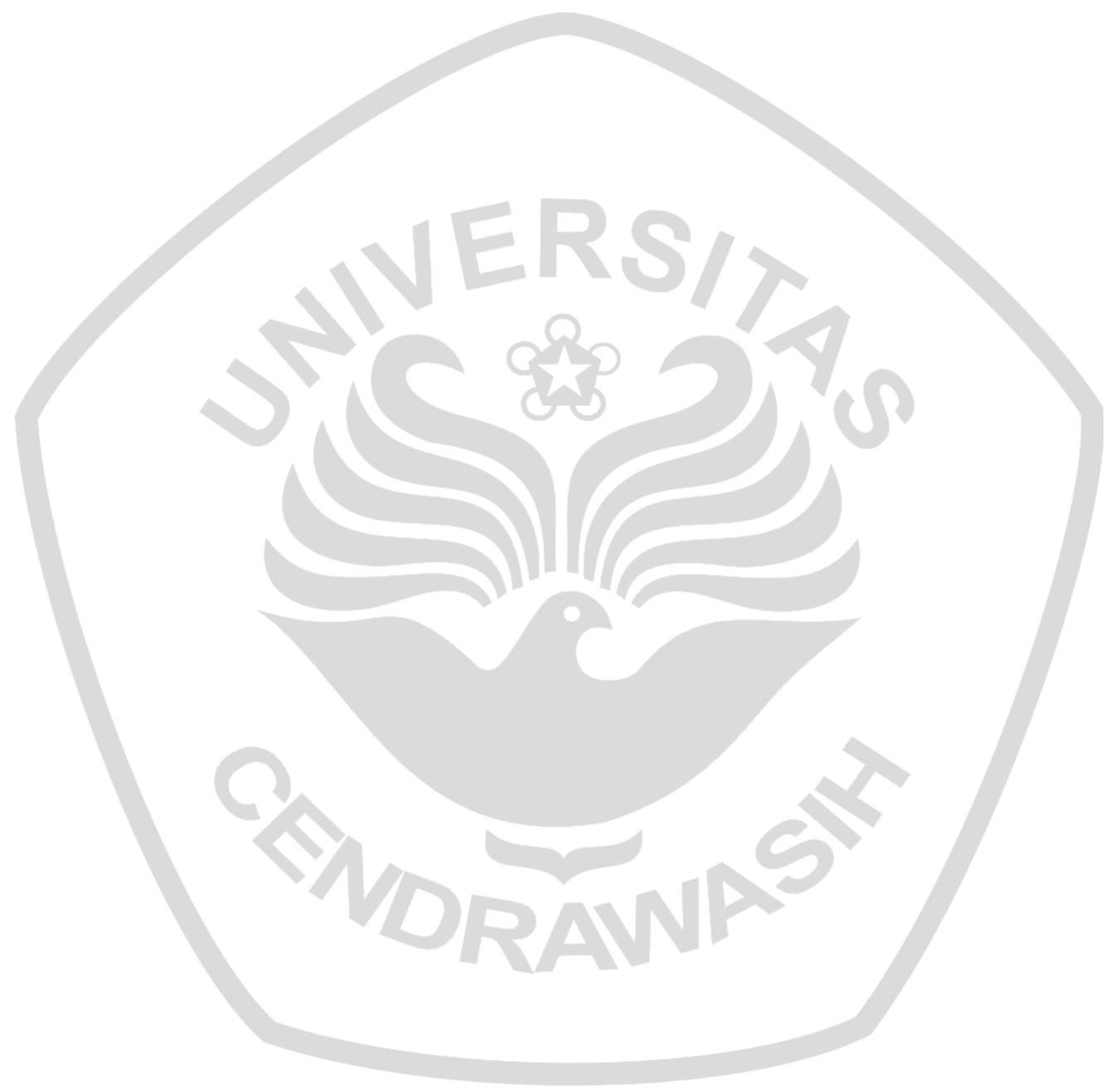

